\section{Comparison of an Antitranspirant Spray, a Polyacrylamide Gel, and Wind Protection on Early Growth of Muskmelon}

\author{
Laurie Hodges ${ }^{1}$ and Entin Daningsih ${ }^{2}$ \\ Department of Agronomy and Horticulture, University of Nebraska, Lincoln \\ NE 68583-0724
}

\author{
James R. Brandle ${ }^{3}$ \\ School of Natural Resources, University of Nebraska, Lincoln NE 68583-0814
}

Additional index words. wind, stand establishment, cantaloupe, shelterbelt, windbreak, microclimate, transplant

\begin{abstract}
Field experiments were conducted over 4 years to evaluate the effects of antitranspirant (Folicote, Aquatrol Inc., Paulsboro, N.J.) and polyacrylamide gel (SuperSorb, Aquatrol Inc., Paulsboro, N.J.) on early growth of transplanted muskmelon grown either protected by tree windbreaks or exposed to seasonal winds. A randomized complete block design (RCBD) with split plot arrangement was used with wind protection (sheltered and exposed) areas as the main treatment and use of an antitranspirant spray or gel dip as subtreatments. Based on destructive harvests in the field, treatments and subtreatments did not affect dry weight or leaf area index in the first 2 years. Specific contrasts, however, showed that gel application significantly increased fresh weight, dry weight, and leaf area index over that of the untreated transplants whereas the spray application tended to reduce these factors during the first 3 weeks after transplanting. Significant differences between gel and spray subtreatments disappeared by 5 weeks after transplanting. Shelterbelts ameliorated crop microclimate thereby enhancing plant growth. Significantly, wind velocity at canopy height was reduced $40 \%$ on average and soil temperatures were about $4 \%$ warmer in the sheltered plots compared to the exposed plots during the first 5 weeks post-transplant. Muskmelon plants in the sheltered areas grew significantly faster than the plants in the exposed areas in 2 of the 3 years reported, with the 3-year average fresh weight increased by $168 \%$ due to wind protection. Overall transplanting success and early growth were enhanced the most by wind protection, followed by the polyacrylamide gel root dip, and least by the antitranspirant foliar spray. We conclude that microclimate modification by wind speed reduction can increase early muskmelon plant growth more consistently than the use of polyacrylamide gel as a root dip at transplanting or the use of an antitranspirant spray. A polyacrylamide gel root dip generally will provide more benefit during early muskmelon growth than the use of an antitranspirant spray.
\end{abstract}

Transplanted plants may be subjected to water stress soon after planting due to wind, heat, cold, or a combination of these climatic factors. While these conditions can occur in any production area, wind and large fluctuating temperatures are particularly characteristic of the continental climate in the Great Plains. Water stress during early plant development can affect plant establishment and may reduce yield. Avoidance of water stress can reduce the risk of crop loss. There are two main methods to reduce water stress in transplanted crops:

Received for publication 17 Oct. 2005. Accepted for publication 16 Nov. 2005. Journal series 14707 NebraskaAgricultural Research Division, University of Nebraska. Use of trade names does not imply endorsement of the products named nor criticism of similar ones not named. Research was supported by CSREES Project NE20-050 and the McIntire-Stennis Cooperative Forestry Research Program. We thank Linda J. Young for statistical support.

${ }^{1}$ Associate professor. To whom reprint requests should be addressed; e-mail lhodges@unl.edu.

${ }^{2}$ Former graduate student.

${ }^{3}$ Professor.
1964; Zhang et al., 1999). Our focus in this research was on the critical first few weeks after transplanting and compared the two approaches for transplant establishment - antitranspirant foliar spray or amending the immediate root zone of the transplant with a water-holding polymer - with the effect of microclimate amelioration by shelterbelts during transplant establishment. The research was conducted under field conditions.

\section{Materials and Methods}

Research was conducted during the growing seasons of 1991, 1992, 1993, and 1994 at the University of Nebraska Agricultural Research and Development Center at Mead, Nebr. (lat. $41^{\circ} 29^{\prime} \mathrm{N}$, long. $96^{\circ} 23^{\prime} \mathrm{W}, 354 \mathrm{~m}$ above mean sea level). The soil was a Typic Argiudoll (Sharpsburg silty clay loam). A randomized complete block design was used with a split plot arrangement of subtreatments. The main treatments were areas protected from the wind using replicated shelterbelts (tree windbreaks) and comparable replicated areas exposed to the wind. These are described in more detail below.

Seven subtreatments were applied randomly to the muskmelon transplants in each main treatment in 1991. The subtreatments consisted of antitranspirant foliar spray (Folicote, Aquatrol Corp.) and polyacrylamide gel (SuperSorb, Aquatrol Corp.) applied singularly and in combination as follows: 1) control (without any chemical treatment); 2) dip (SuperSorb gel polymer at transplanting); 3) spray (folicote antitranspirant at transplanting); 4) dip and spray at transplanting; 5) spray at transplanting and again after 2 weeks; 6) dip at transplanting and spray after 2 weeks; 7) spray once 2 weeks after transplanting. In years subsequent to 1991, the number of replications was increased to four and the seven subtreatments were reduced to three: control (without chemical treatment); dip (transplant root ball dip in polyacrylamide gel slurry at transplanting); and spray (foliage spray with antitranspirant at transplanting and again 2 weeks after transplanting). For simplicity, only the subtreatments in common across years are included in this report.

Folicote was prepared as a $5 \%$ solution in water (1:20 $\mathrm{v} / \mathrm{v}$ dilution). Warm water was added to the Folicote, stirring slowly to form an emulsion. Then a nonionic surfactant [Biofilm (alkylarypolyethoxethanol), Aquatrol Inc., Paulsboro, N.J.] was added to make a $0.5 \%$ concentration of surfactant. The antitranspirant spray was applied over the top of the transplanted muskmelon to runoff using a backpack sprayer at $3.9 \mathrm{MPa}$, walking about $0.45 \mathrm{~m} \cdot \mathrm{s}^{-1}$ with the spray nozzle about $30 \mathrm{~cm}$ above the muskmelon foliage. A slurry of SuperSorb (polymer gel) was prepared as $85 \mathrm{~g} / 3.78 \mathrm{~L}$ of water. Roots were dipped in the gel suspension to the top of the root ball immediately before placement in the soil. The mixture was stirred frequently to maintain suspension of the gel.

Wind protection for the main treatments was provided by replicated systems of mature mixed 
conifer and hardwood shelterbelts established in 1966. Sheltered muskmelon plots were in the highly protected leeward zone within $2 \mathrm{H}$ or twice the height of the shelterbelt. Within the prevailing spring or summer wind direction (south-southeast to south-southwest), there were no shelterbelts in any direction within $15 \mathrm{H}$ of the exposed plots.

Microclimate parameters were monitored and recorded on automatic dataloggers (CR10; Campbell Scientific, Inc., Logan, Utah). Wind speed was measured with a three cup anemometer (model 12102; R.M. Young, Traverse City, Mich.) at height of $58 \mathrm{~cm}$, just above the canopy height of mature muskmelon. Air temperature and relative humity were measured at $45 \mathrm{~cm}$, about the height of mature muskmelon foliage, using a temperature and relative humidity probe (model HMP35C or XN217; Campbell Scientific, Inc.). Soil temperatures were measured with copper constatan thermocouples at a depth of $7.5 \mathrm{~cm}$. Data were recorded every $60 \mathrm{~s}$ and averaged hourly. Daily averages of the microclimate data also were recorded automatically. Soil moisture at the $15 \mathrm{~cm}$ depth was obtained using the gravimetric method. Eight soil samples were taken weekly for each measurement at each treatment plot. Soil was dried at 70 ${ }^{\circ} \mathrm{C}$ for $5 \mathrm{~d}$. Precipitation data was obtained from recorders located within $0.8 \mathrm{~km}$ of the muskmelon plots at Mead, Nebr., through the High Plains Climate Center, School of Natural Resources, University of Nebraska-Lincoln (http://www.hprcc.unl.edu/).

In 1991, four dataloggers were installed. Two dataloggers were installed in the exposed areas while the other two were in sheltered areas. In 1992, five dataloggers were used. Dataloggers were placed into each of the three replicated sheltered areas. The remaining two dataloggers were placed in two of the three exposed areas. In 1993 and 1994, eight dataloggers were used to monitor conditions in each of the four replications of the two main treatments.

In 1991, each plot was $1.8 \mathrm{~m}$ wide with a single row of muskmelon centered on the plot. Guard rows were planted with 7 muskmelons per $4.2 \mathrm{~m}$ spaced $61 \mathrm{~cm}$ apart in-row. Treatment rows were planted with 14 muskmelon spaced $30.5 \mathrm{~cm}$ apart in-row. This allowed for destructive harvest to determine leaf area indices and leave a final plant spacing of 61 $\mathrm{cm}$ within rows. In subsequent years, plots were widened to $3 \mathrm{~m}$ to facilitate harvesting of the subplots and planting beds were raised $10 \mathrm{~cm}$. Plots were not irrigated.

Growth measurements were made through the first 6 to 8 weeks after transplanting by measuring the leaf area and the total fresh and dry weight of leaf and shoot. Leaf area was measured with an area meter (LI-3100; LI-COR, Lincoln, Nebr.). The leaf area index (LAI) was based on the following equation (Hunt, 1982): LAI = leaf area $\left(\mathrm{cm}^{2}\right) /$ ground area $\left(\mathrm{cm}^{2}\right)$. Transplants were cut just above the cotyledonary node. Ground area used for LAI calculation was the final plant spacing or $2 \times 5400 \mathrm{~cm}^{2}$ in 1991 and $2 \times 10800 \mathrm{~cm}^{2}$ in 1992, 1993, and 1994.

Field experiment 1991. 'Hiline' muskmelons (Asgrow Seed Co., now Seminis, Oxard, Calif.) were seeded in the greenhouse on May 5 in a vermiculite-perlite mix in plugs with a volume of about $30 \mathrm{~cm}^{3}$ (Growing Systems 72 cell tray, Morton's Horticultural Products, Inc., McMinnville, Tenn.) and transferred to a lath house on 17 May. Fertilization was with 9-45-15 (540 ppm N, 1180 ppm P, and 747 ppm K). Plants were in a single leaf stage when transplanted and trays were watered prior to transplanting. Transplanting was on 28 May in sheltered and exposed areas with the subtreatments of antitranspirant spray and/or polyacrylamide gel dip applied at transplanting. Antitranspirant spray was applied the second time on 14 June [18 d after transplanting (DAT)]. Plant growth was measured twice in 1991. The first measurement was 19 June (22 DAT) and the second measurement was 2 July (35 DAT).

Field experiment in 1992. Transplants were seeded in the greenhouse on $28 \mathrm{Apr}$. Transplanting was on 20 May. All seven subtreatments were applied. Growth measurements were taken four times during early muskmelon stand establishment and plant development. There was an initial measurement at the time of transplanting, the second week or 16 DAT, the third week or 21 DAT, and the fifth week or 35 DAT. The destructive harvests for growth measurements resulted in a final stand of $61 \mathrm{~cm}$ within the rows 5 weeks after transplanting, approximately the time when the plants were vining and the first female flowers appeared.

Field experiment in 1993. Transplants were seeded in the greenhouse on $28 \mathrm{Apr}$. Transplanting was on 9 June. The muskmelon were transplanted in triple rows on a single bed with $30.5 \mathrm{~cm}$ between plants within each row and between rows. Destructive sampling for plant growth resulted in thinning the plants to a final single row with plants $61 \mathrm{~cm}$ apart 6 weeks after transplanting. Each treatment, shelter or exposed, was replicated four times. The seven subtreatments were reduced to three subtreatments: 1) control; 2) root dipped in the polyacrylamide gel slurry at transplanting; and 3) sprayed with antitranspirant at transplanting and again 2 weeks after transplanting. Within each replication there were four subtreatment areas consisting of three beds, one for each subtreatment. Each row for subtreatment was selected randomly within the sampling area. Growth measurements were taken four times during early muskmelon plant development: an initial measurement just before the transplants were planted, at 21, 28, and 33 DAT.

Field experiment in 1994. Transplants were seeded in the greenhouse on 5 May and transplanted to the field on 14 June. Transplants were established in triple rows on a single bed with $30.5 \mathrm{~cm}$ between plants within and between each row. There were four replications and three subtreatments as described for 1993. The growth measurements were taken four times at transplanting and 21, 28, and 34 DAT.

Data analysis. The general linear model (GLM) procedure was used in the SAS statistical package (SAS Institute, Cary, N.C.) using a randomized complete-block design (RCBD) with a split-plot arrangement. Two GLM models were used in SAS analysis. The first GLM model tested the effects of treatment and subtreatments individually on early muskmelon growth (total fresh and dry weight, and leaf area index) and tested for interaction between treatment and subtreatment. The second GLM model tested the effect of subtreatments within the treatment as a nested model to see if subtreatments effects in sheltered areas were the same as in the exposed areas. The two GLM models were run twice with different sets of planned orthogonal contrasts with single

Table 1. Average hourly microclimate data from 1991 to 1994 in muskmelon plots protected from the wind by shelterbelts or exposed to wind stress.

\begin{tabular}{|c|c|c|c|c|c|c|c|c|c|c|c|c|c|c|c|c|}
\hline \multirow[b]{2}{*}{ Year } & \multirow{2}{*}{$\begin{array}{c}\text { Days of } \\
\text { year }\end{array}$} & \multirow[b]{2}{*}{$\mathrm{DAT}^{\mathrm{z}}$} & \multicolumn{2}{|c|}{$\begin{array}{l}\text { Wind speed } \\
\left(\mathrm{m} \cdot \mathrm{s}^{-1}\right)\end{array}$} & \multicolumn{2}{|c|}{$\begin{array}{l}\text { Vapor pressure } \\
\text { deficit }(\mathrm{kPa})\end{array}$} & \multicolumn{2}{|c|}{$\begin{array}{l}\text { Precipitation } \\
\text { Percent of }\end{array}$} & \multicolumn{2}{|c|}{$\begin{array}{l}\text { Air temp } \\
\left({ }^{\circ} \mathrm{C}\right)\end{array}$} & \multicolumn{2}{|c|}{$\begin{array}{l}\text { Soil temp } \\
\left({ }^{\circ} \mathrm{C}\right)\end{array}$} & \multicolumn{2}{|c|}{$\begin{array}{l}\text { Accumulated } \\
\text { GDHT }^{x}\end{array}$} & \multicolumn{2}{|c|}{$\begin{array}{l}\text { Accumulated } \\
\text { GDHS }^{w}\end{array}$} \\
\hline & & & Sheltered & Exposed $^{y}$ & Sheltered & Exposed & $\mathrm{mm}$ & 30 -year avg & Sheltered & Exposed & Sheltered & Exposed & Sheltered & Exposed & Sheltered & Exposed \\
\hline \multirow[t]{2}{*}{1991} & $148-170$ & 22 & 1.06 & $2.57^{*}$ & 0.86 & 0.89 & 213 & 241 & 24.4 & 24.3 & 25.1 & $24.6^{*}$ & 4249 & 4552 & 4989 & 4967 \\
\hline & $148-183$ & 35 & 1.07 & $2.60^{*}$ & 1.08 & 1.07 & 241 & 177 & 25.5 & 25.3 & 26.6 & $25.4^{*}$ & 8303 & 8181 & 9265 & 8254 \\
\hline \multirow[t]{3}{*}{1992} & $141-157$ & 16 & 1.02 & $2.16^{*}$ & 0.58 & 0.75 & 42 & 18 & 15.7 & 15.7 & 18.4 & $17.5^{*}$ & 945 & 937 & 1358 & 1005 \\
\hline & $141-162$ & 23 & 1.01 & $2.11^{*}$ & 0.57 & 0.73 & 43 & 18 & 16.4 & 16.4 & 18.9 & $17.9^{*}$ & 1373 & 1368 & 1982 & 1442 \\
\hline & $141-176$ & 35 & 1.04 & $2.13^{*}$ & 0.80 & 0.93 & 78 & 26 & 18.5 & 18.4 & 21.1 & $20.1^{*}$ & 3611 & 3514 & 5015 & 4113 \\
\hline \multirow[t]{3}{*}{1993} & $160-181$ & 21 & 2.15 & $3.34^{*}$ & 0.76 & 0.80 & 162 & 199 & 22.4 & 22.3 & 24.2 & $23.1^{*}$ & 3729 & 3797 & 4250 & 4227 \\
\hline & $160-188$ & 28 & 2.12 & $3.27^{*}$ & 0.73 & 0.77 & 191 & 187 & 22.8 & 22.6 & 24.5 & $23.5^{*}$ & 5157 & 5183 & 5883 & 5834 \\
\hline & $160-193$ & 33 & 2.11 & $3.23^{*}$ & 0.70 & 0.74 & 211 & 180 & 22.9 & 22.7 & 24.6 & $23.8^{*}$ & 6112 & 6116 & 7016 & 7042 \\
\hline \multirow[t]{3}{*}{1994} & $165-186$ & 21 & 2.16 & $2.73^{*}$ & 0.94 & $0.84^{*}$ & 196 & 257 & 24.9 & 24.6 & 27.7 & $26.5^{*}$ & 4581 & 4456 & 6057 & 5516 \\
\hline & $165-193$ & 28 & 2.16 & $2.77^{*}$ & 0.92 & $0.82^{*}$ & 213 & 219 & 24.4 & 24.3 & 27.6 & $26.5^{*}$ & 5854 & 5699 & 8007 & 7319 \\
\hline & $165-199$ & 34 & 2.14 & $2.70^{*}$ & 0.87 & $0.77^{*}$ & 215 & 187 & 24.1 & 23.8 & 27.3 & $26.4^{*}$ & 6842 & 6670 & 9537 & 6670 \\
\hline
\end{tabular}

${ }^{\mathrm{z}} \mathrm{DAT}=$ days after transplanting.

${ }^{\mathrm{x}} \mathrm{GDHT}=$ accumulative heat units based on hourly air temperatures using base temperature of $15.6^{\circ} \mathrm{C}$.

${ }^{\mathrm{w}} \mathrm{GDHS}=$ accumulative heat units based on hourly soil temperatures using base temperature of $15.6^{\circ} \mathrm{C}$.

*Significant differences between sheltered and exposed values at $p \leq 0.05$. 
Table 2. Percent soil moisture of muskmelon areas either sheltered from the wind by tree windbreaks or exposed to wind in open wind conditions. $p>\mathrm{F}=$ probability of a greater $\mathrm{F}$ value across columns within a year and day of year.

\begin{tabular}{|c|c|c|c|c|}
\hline \multirow{2}{*}{$\begin{array}{l}\text { Year/ } \\
\text { day of year }\end{array}$} & \multirow[b]{2}{*}{ Date } & \multicolumn{2}{|c|}{ Treatment } & \multirow[b]{2}{*}{$p>\mathrm{F}$} \\
\hline & & Sheltered & Exposed & \\
\hline \multicolumn{5}{|l|}{1991} \\
\hline 169 & 18 June & 24.13 & 21.37 & 0.1592 \\
\hline 183 & 2 July & 16.62 & 17.28 & 0.7755 \\
\hline 197 & 16 July & 20.38 & 19.10 & 0.4460 \\
\hline \multicolumn{5}{|l|}{1992} \\
\hline 149 & 28 May & 21.23 & 21.10 & 0.9316 \\
\hline 155 & 3 June & 19.22 & 19.76 & 0.3959 \\
\hline 162 & 10 June & 18.73 & 20.35 & 0.3001 \\
\hline 169 & 17 June & 24.29 & 25.89 & 0.4530 \\
\hline 176 & 24 June & 17.82 & 22.12 & 0.1284 \\
\hline \multicolumn{5}{|l|}{1993} \\
\hline 159 & 8 June & 19.25 & 20.38 & 0.2208 \\
\hline 166 & 15 June & 17.59 & 18.32 & 0.6434 \\
\hline 181 & 30 June & 23.68 & 22.26 & 0.0840 \\
\hline 192 & 11 July & 25.73 & 21.73 & 0.0257 \\
\hline \multicolumn{5}{|l|}{1994} \\
\hline 166 & 15 June & 14.23 & 11.66 & 0.1879 \\
\hline 173 & 22 June & 22.37 & 24.93 & 0.0010 \\
\hline 194 & 13 July & 24.36 & 25.79 & 0.1676 \\
\hline 200 & 19 July & 20.34 & 18.73 & 0.3209 \\
\hline
\end{tabular}

degrees of freedom. The first set of orthogonal six contrasts compared the seven subtreatments and determined which subtreatments of polyacrylamide gel and antitranspirant foliar spray would be continued for the subsequent years. The six contrasts were also tested within

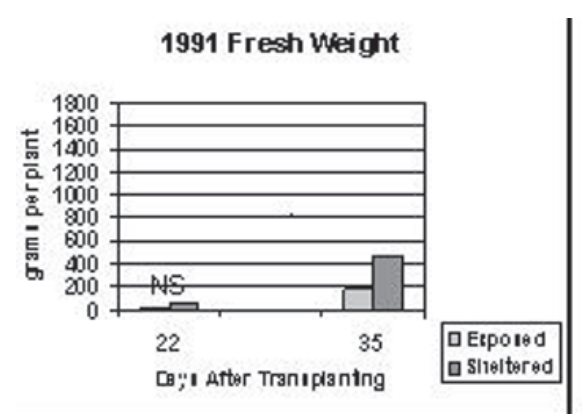

the sheltered and exposed areas. In the second run of the GLM analysis, the contrasts were set differently from the first run. These contrasts compared the control to each of the chemical treatments under the wind protected and exposed locations.

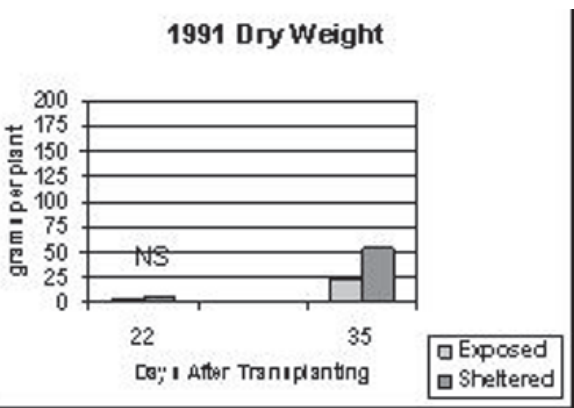

\section{Results and Discussion}

Microclimate in sheltered and exposed socations. Precipitation received during the period of plant measurements in all years was adequate, averaging $54 \mathrm{~mm}$ per week except in 1992 when it averaged $16 \mathrm{~mm}$ per week (Table 1).

From the date of transplanting to 22 DAT in 1991, the total precipitation was $213 \mathrm{~mm}$ compared to a normal precipitation of 136 $\mathrm{mm}$ for this time period. Cold temperatures and precipitation during the 2 weeks after transplanting in 1992 contributed to herbicide injury, poor crop growth and nonuniformity of response. In 1992, the air temperature at canopy height from 26 through 28 May (6 to 8 DAT) dropped below $5^{\circ} \mathrm{C}$, ranging between -3.6 to $0.1^{\circ} \mathrm{C}$ for these $3 \mathrm{~d}$ ( 6 to $\left.8 \mathrm{DAT}\right)$. No rainfall was received during this time.

However, within $48 \mathrm{~h}$ after transplanting, $25 \mathrm{~mm}$ of rain fell and by 8 DAT total accumulated rainfall was $30 \mathrm{~mm}$. The prolonged low temperature and wet soil severely stunted muskmelon growth. Sasson and Bramlage (1981) found that chilling injury to 8-d-old cucumber seedlings (Cucumis sativus L.) exposed to $2^{\circ} \mathrm{C}$ for $48 \mathrm{~h}$ was reversible if immediately followed by exposure to $25^{\circ} \mathrm{C}$; if not, the seedlings would likely die. Although
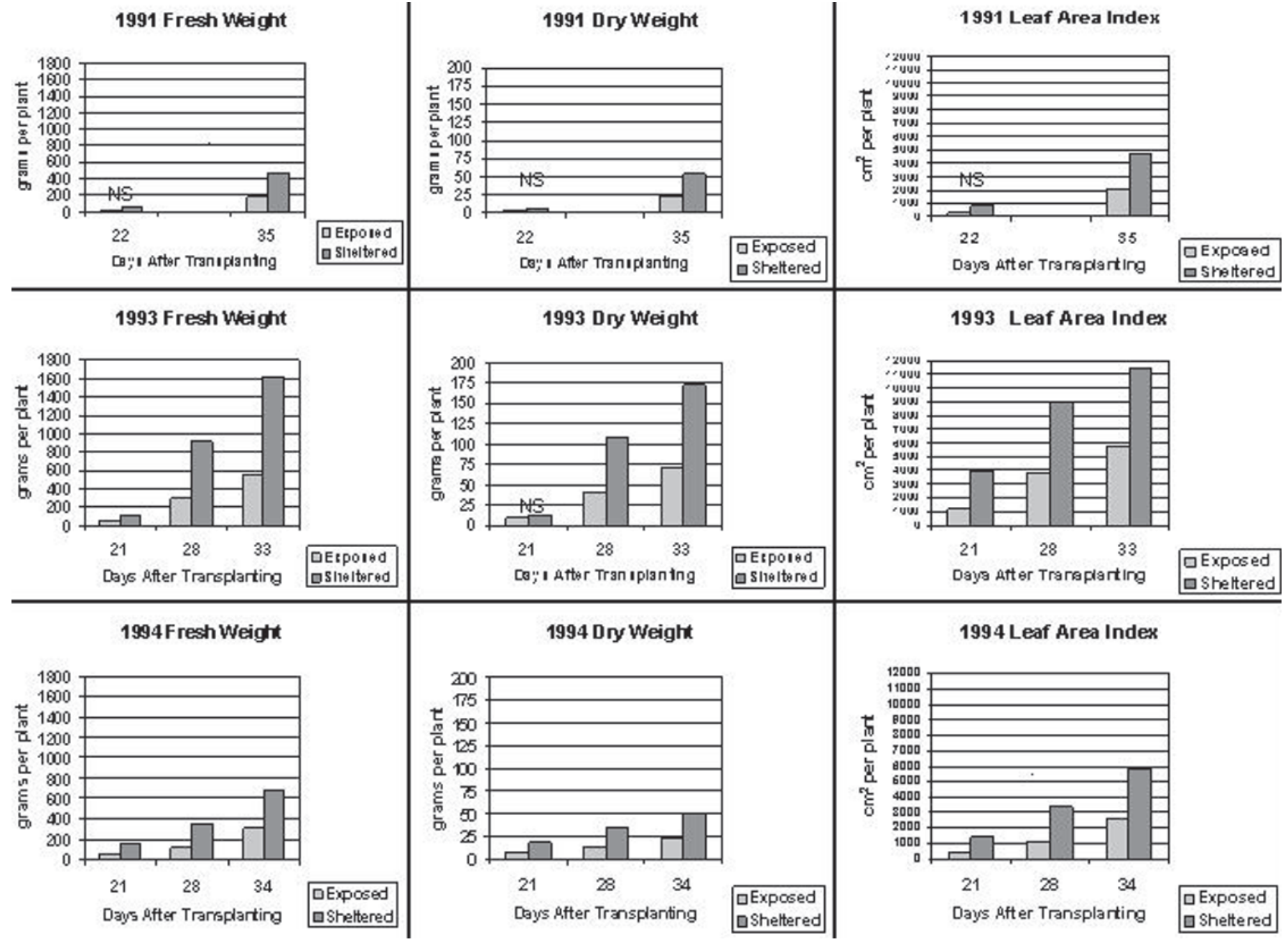

Fig. 1. Development of muskmelon transplants exposed or sheltered from wind stress. Differences between columns within days after transplanting are significant $(P \leq 0.10)$ unless noted otherwise. Values are averages of the three subtreatments: control, root dip, and foliar spray. 
there is some research indicating that the use of antitranspirants may offer some protection against chilling temperatures (Christiansen and Ashworth, 1978; El-Sayed, 1991; Han, 1990; Semeniuk et al., 1986), we did not observe any differences in injury attributable to either the presence or absence of any subtreatment (root dip or foliar spray) or any difference between the sheltered and exposed plots. Data from 1992 was dropped from analysis and will not be further discussed. In 1993, precipitation by the transplanting date was $188 \mathrm{~mm}$ more than normal. The following year, precipitation received by transplant date was $199 \mathrm{~mm}$ less than normal with the resulting soil moisture content during the first week after transplanting being only $14 \%$ and $12 \%$ in the sheltered and exposed areas, respectively, in 1994 (Table 2).

Average hourly air temperatures for all years were not significantly different between sheltered and exposed areas (Table 1). However, average hourly air temperatures during early growth of muskmelon in sheltered areas were higher by 0.1 to $0.3{ }^{\circ} \mathrm{C}$.

In contrast to the slight differences in air temperatures, average hourly soil temperatures from sheltered areas were significantly warmer by $2 \%$ to $6 \%\left(0.5\right.$ to $\left.1.2{ }^{\circ} \mathrm{C}\right) \mathrm{com}$ - pared to soil temperatures in exposed areas (Table 1).

Average hourly wind speeds also were significantly different between sheltered and exposed areas for all years (Table 1). In 1991 during 22 and 35 DAT the average hourly wind speed in sheltered areas was reduced by $59 \%$ $\left(2.6 \mathrm{vs} .1 .1 \mathrm{~m} \cdot \mathrm{s}^{-1}\right)$. Wind speeds in 1992 were reduced by $32 \%$ by shelterbelts (2.1 vs. 1.0 $\left.\mathrm{m} \cdot \mathrm{s}^{-1}\right)$. In 1993, the average hourly wind speed in sheltered areas were reduced by about $35 \%$ (3.3 vs. $\left.2.1 \mathrm{~m} \cdot \mathrm{s}^{-1}\right)$. In 1994, the average hourly wind speed in sheltered areas was reduced by about $22 \%\left(2.7\right.$ vs. $\left.2.2 \mathrm{~m} \cdot \mathrm{s}^{-1}\right)$.

Microclimate effects on vegetative growth. Using a split plot analysis to evaluate the data for the vegetative growth at 22 and 35 DAT, neither the main treatments (wind exposure) nor the subtreatments (spray, dip, or control) predictably affected plant growth (Table 3 ). However, contrast analysis of the average of the three subtreatments found significant differences $(p \leq 0.10)$ between transplants grown in wind protected and wind exposed locations (Fig. 1). In 1991, fresh weight of sheltered plants was $157 \%$ to $182 \%$ greater than the exposed plants while dry weight and LAI of plants grown in the wind protected areas increased on average 128\% (Table 3).
In 1993 (Table 4), plants in areas sheltered from the wind were two to three times larger than those in exposed areas with significant differences in total fresh weight and LAI at $p \leq 0.05$ for all three destructive sampling periods during the first 33 DAT. Dry weight of the 1993 transplants was increased also by wind protection at 28 and 33 DAT but not at 21 DAT. An increased relative humidity of about $2.5 \%$ and a reduced vapor pressure deficit of $0.01 \mathrm{kPa}$ at canopy height due the protection of shelterbelt may have contributed to the faster growth of muskmelon transplants in the sheltered areas than those in the exposed areas. In addition, wind speed in sheltered areas was reduced about $55 \%$ of that in exposed areas. These microclimatic factors suggest that the transpiration from leaves in the sheltered areas was probably less than in the exposed areas.

In 1994, precipitation was again about twice the normal for comparable time periods (Table 1). Despite this, soil moisture was about 3\% lower in the exposed plots than the sheltered plots, possibly due to the evaporative effect of the wind. The average hourly wind speed in the sheltered area was reduced by about $22 \%$ from the exposed area, although the vapor pressure deficit was significantly higher in the sheltered area during this period of plant growth.

Table 3. Development of muskmelon transplants treated with a foliar antitranspirant spray or a polyacrylamide gel root dip and grown either sheltered from the wind by tree windbreaks or exposed to wind stress in 1991. Means \pm standard errors; $p=$ significance of a greater or equal $\mathrm{F}$ value.

\begin{tabular}{|c|c|c|c|c|c|}
\hline \multirow[b]{3}{*}{ Variable } & \multirow[b]{3}{*}{ Subtreatment } & \multicolumn{2}{|c|}{$22 \mathrm{DAT}^{\mathrm{z}}$} & \multicolumn{2}{|c|}{35 DAT } \\
\hline & & \multicolumn{2}{|c|}{ Treatment } & \multicolumn{2}{|c|}{ Treatment } \\
\hline & & Sheltered & Exposed & Sheltered & Exposed \\
\hline \multirow[t]{3}{*}{ Total fresh weight (g/plant) } & Control & $60.5 \pm 44.5$ & $21.83 \pm 7.4$ & $410.1 \pm 154.6$ & $191.7 \pm 43.7$ \\
\hline & $\operatorname{Dip}^{y}$ & $80.0 \pm 31.0$ & $31.56 \pm 9.7$ & $561.3 \pm 90.7$ & $190.5 \pm 6.8$ \\
\hline & Spray $^{\mathrm{x}}$ & $60.0 \pm 35.0$ & $17.8 \pm 6.0$ & $450.5 \pm 243.5$ & $170.9 \pm 7.1$ \\
\hline$P$, between columns & & \multicolumn{2}{|c|}{0.2395} & \multicolumn{2}{|c|}{0.1023} \\
\hline \multirow{3}{*}{ Total dry weight (g/plant) } & Control & $5.6 \pm 3.7$ & $2.5 \pm 0.8$ & $46.2 \pm 15.9$ & $24.2 \pm 5.2$ \\
\hline & Dip & $7.7 \pm 2.2$ & $3.6 \pm 0.9$ & $62.1 \pm 7.3$ & $24.2 \pm 0.6$ \\
\hline & Spray & $5.7 \pm 2.6$ & $2.0 \pm 0.6$ & $51.8 \pm 26.9$ & $21.8 \pm 1.3$ \\
\hline$P$, between columns & & \multicolumn{2}{|c|}{0.2337} & \multicolumn{2}{|c|}{0.1097} \\
\hline \multirow{3}{*}{$\mathrm{LAI}^{\mathrm{w}}\left(\mathrm{cm}^{2}\right)$} & Control & $697.8 \pm 483.0$ & $287.2 \pm 94.6$ & $4157.6 \pm 1240.4$ & $2099.9 \pm 467.7$ \\
\hline & Dip & $926.1 \pm 304.7$ & $396.7 \pm 113.2$ & $5553.7 \pm 520.0$ & $2133.9 \pm 420.0$ \\
\hline & Spray & $740.2 \pm 410.7$ & $237.5 \pm 77.4$ & $4337.2 \pm 2141.3$ & $1921.0 \pm 63.5$ \\
\hline$P$, between columns & & \multicolumn{2}{|c|}{0.2236} & \multicolumn{2}{|c|}{0.0860} \\
\hline
\end{tabular}

${ }^{2} \mathrm{DAT}=$ days after transplanting.

${ }^{\mathrm{y}}$ Dip $=$ Supersorb polyacrylamide gel at transplanting.

${ }^{\mathrm{x}}$ Spray $=$ antitranspirant at transplanting.

${ }^{\mathrm{w}} \mathrm{LAI}=$ leaf area index.

Table 4. Development of muskmelon transplants treated with a foliar antitranspirant spray or a polyacrylamide gel root dip and grown either sheltered from the wind by tree windbreaks or exposed to wind stress in 1993. Means \pm standard errors; $p=$ significance of a greater or equal $\mathrm{F}$ value.

\begin{tabular}{|c|c|c|c|c|c|c|c|}
\hline \multirow[b]{2}{*}{ Variables } & \multirow[b]{2}{*}{ Subtreatment } & \multicolumn{2}{|c|}{$21 \mathrm{DAT}^{\mathrm{z}}$} & \multicolumn{2}{|c|}{28 DAT } & \multicolumn{2}{|c|}{33 DAT } \\
\hline & & Sheltered & Exposed & Sheltered & Exposed & Sheltered & Exposed \\
\hline Total fresh weight (g/plant) & $\operatorname{Dip}^{y}$ & $119.0 \pm 15.3$ & $63.4 \pm 19.6$ & $983.4 \pm 44.0$ & $283.5 \pm 77.8$ & $1601.6 \pm 173.1$ & $569.0 \pm 212.6$ \\
\hline \multirow{3}{*}{ Total dry weight (g/plant) } & Control & $12.1 \pm 0.9$ & $9.6 \pm 2.8$ & $112.9 \pm 3.1$ & $39.1 \pm 11.7$ & $170.6 \pm 16.6$ & $61.1 \pm 14.5$ \\
\hline & Dip & $13.9 \pm 1.5$ & $9.7 \pm 3.2$ & $113.0 \pm 3.3$ & $41.3 \pm 10.5$ & $173.8 \pm 16.4$ & $72.3 \pm 23.2$ \\
\hline & Spray & $12.7 \pm 1.1$ & $9.4 \pm 3.6$ & $97.8 \pm 8.9$ & $43.2 \pm 15.7$ & $175.2 \pm 10.5$ & $76.6 \pm 20.9$ \\
\hline & Dip & $4326.8 \pm 461.4$ & $1190.3 \pm 463.9$ & $11448.0 \pm 470.2$ & $3900.7 \pm 589.4$ & $11448.0 \pm 730.2$ & $5882.4 \pm 949.5$ \\
\hline & Spray & $3827.9 \pm 351.2$ & $1214.5 \pm 546.9$ & $9024.9 \pm 652.2$ & $3914.8 \pm 740.4$ & $11879.9 \pm 498.0$ & $6357.2 \pm 1013.0$ \\
\hline$P$, between treatments & & \multicolumn{2}{|c|}{0.0024} & \multicolumn{2}{|c|}{0.0070} & \multicolumn{2}{|c|}{0.0235} \\
\hline
\end{tabular}

${ }^{2} \mathrm{DAT}=$ days after transplanting.

${ }^{\mathrm{y}}$ Dip $=$ Supersorb polyacrylamide gel .

${ }^{\mathrm{x}}$ Spray $=$ Folicote antitranspirant.

"LAI $=$ leaf area index. 
Table 5. Development of muskmelon transplants treated with a foliar antitranspirant spray or a polyacrylamide gel root dip and grown either sheltered from the wind by tree windbreaks or exposed to wind stress in 1994. Data reflect the means the their standard errors; $p=$ significance of a greater or equal F value.

\begin{tabular}{|c|c|c|c|c|c|c|c|}
\hline \multirow[b]{2}{*}{ Variables } & \multirow[b]{2}{*}{ Subtreatment } & \multicolumn{2}{|c|}{$21 \mathrm{DAT}^{\mathrm{z}}$} & \multicolumn{2}{|c|}{28 DAT } & \multicolumn{2}{|c|}{34 DAT } \\
\hline & & Sheltered & Exposed & Sheltered & Exposed & Sheltered & Exposed \\
\hline \multicolumn{8}{|l|}{ Total fresh weight (g/plant) } \\
\hline & Control & $149.5 \pm 10.3$ & $49.5 \pm 6.9$ & $342.7 \pm 36.5$ & $119.2 \pm 19.5$ & $702.6 \pm 51.8$ & $265.9 \pm 38.2$ \\
\hline & $\operatorname{Dip}^{y}$ & $175.9 \pm 8.6$ & $62.2 \pm 7.2$ & $370.7 \pm 28.4$ & $146.0 \pm 24.1$ & $711.6 \pm 57.3$ & $379.3 \pm 64.4$ \\
\hline & Spray $^{\mathrm{x}}$ & $121.0 \pm 7.9$ & $36.1 \pm 4.2$ & $330.8 \pm 25.9$ & $86.3 \pm 16.5$ & $628.8 \pm 56.2$ & $270.9 \pm 57.3$ \\
\hline$P$, between treatments within DAT & & \multirow{2}{*}{\multicolumn{2}{|c|}{0.0005}} & \multirow{2}{*}{\multicolumn{2}{|c|}{0.0071}} & \multirow{2}{*}{\multicolumn{2}{|c|}{0.0219}} \\
\hline \multicolumn{2}{|l|}{ Total dry weight (g/plant) } & & & & & & \\
\hline & Control & $18.3 \pm 1.0$ & $7.6 \pm 1.0$ & $34.5 \pm 2.7$ & $13.9 \pm 2.0$ & $53.2 \pm 3.8$ & $20.8 \pm 3.1$ \\
\hline & Dip & $20.6 \pm 0.8$ & $9.4 \pm 1.0$ & $36.5 \pm 2.0$ & $16.5 \pm 2.4$ & $50.0 \pm 2.4$ & $26.6 \pm 4.9$ \\
\hline & Spray & $16.1 \pm 0.8$ & $6.8 \pm 1.0$ & $32.8 \pm 2.4$ & $10.1 \pm 1.1$ & $47.9 \pm 3.7$ & $21.4 \pm 4.4$ \\
\hline$P$, between treatments within DAT & & \multirow{2}{*}{\multicolumn{2}{|c|}{0.0009}} & \multirow{2}{*}{\multicolumn{2}{|c|}{0.0036}} & \multicolumn{2}{|c|}{0.0236} \\
\hline \multirow[t]{4}{*}{$\mathrm{LAI}^{\mathrm{w}}\left(\mathrm{cm}^{2}\right)$} & & & & & & & \\
\hline & Control & $1393.7 \pm 92.7$ & $445.3 \pm 51.9$ & $3369.0 \pm 355.8$ & $1151.1 \pm 175.9$ & $6098.0 \pm 505.9$ & $2336.0 \pm 314.8$ \\
\hline & Dip & $1683.9 \pm 79.2$ & $579.3 \pm 66.5$ & $3493.0 \pm 287.4$ & $1415.5 \pm 230.2$ & $5863.1 \pm 488.8$ & $2994.8 \pm 519.4$ \\
\hline & Spray & $1137.2 \pm 74.3$ & $334.3 \pm 39.4$ & $3251.6 \pm 241.2$ & $834.9 \pm 154.0$ & $5555.5 \pm 430.6$ & $2290.9 \pm 445.0$ \\
\hline$P$, between treatments within DAT & & \multicolumn{2}{|c|}{0.0004} & \multicolumn{2}{|c|}{0.0061} & \multicolumn{2}{|c|}{0.0169} \\
\hline
\end{tabular}

${ }^{\text {zDAT }}=$ days after transplanting.

${ }^{y}$ Dip = Supersorb polyacrylamide gel.

${ }^{x}$ Spray $=$ Folicote antitranspirant.

${ }^{\mathrm{w}} \mathrm{LAI}=$ leaf area index.

Total fresh weight of muskmelon plants grown protected from wind stress for 21 through 28 DAT in 1994 was approximately three times that of exposed plants $(p \leq 0.01)$, similar to results in prioryears, with slightly less of a difference (2-fold) between the two main treatments by 34 DAT (Table 5). Averaging all subtreatments, LAI of plants protected from wind stress was three times that of exposed plants 21 and 28 DAT.

Root dip and foliar spray effects on vegetative growth. Plants treated with the polyacrylamide gel root dip in 1991 were larger in terms of total fresh and total dry weight and LAI at both 22 DAT and 35 DAT (Table 3). Contrast analysis showed small but significant differences in muskmelon growth between plants treated with the antitranspirant spray and those with the gel root dip in exposed areas at 35 DAT. The polyacrylamide gel applied to the root ball significantly increased the total fresh weight, dry weight, and LAI over that of plants treated with the antitranspirant spray. Plant growth averaged across subtreatments in sheltered areas generally was greater than that in exposed areas, especially 35 DAT ( $p \leq$ $0.10)$ (Table 3).

In 1993 (Table 4), polyacrylamide gel root dip increased early plant growth at 21 DAT and 28 DAT when compared to the control, whereas the antitranspirant spray tended to reduce plant growth during the first 4 weeks after transplanting. By 33 DAT, plants treated with the antitranspirant spray showed compensatory growth and there was no statistical differences among the subtreatments. Contrast analysis for each harvest showed that, at 21 and 28 DAT, there were significant differences between dip and antitranspirant spray subtreatments in sheltered areas. These differences disappeared by 33 DAT.

Although the antitranspirant and polymer gel as subtreatments did not significantly affect muskmelon dry weight and LAI overall, specific contrast analysis showed that the response to antitranspirant spray and polymer gels was significantly different for LAI in sheltered areas at all observation times $(p=0.00952 ; p$
$=0.0033 ; p=0.0995)$. Application of polymer gels increased the total fresh weight as well as the total dry weight and the LAI in both in sheltered and exposed transplants (Table 4). The transplants treated with polyacrylamide gel had a higher shoot dry weight than those treated with antitranspirant (data are not shown). This indicates that water retention in the root zone by the addition of polyacrylamide gel at transplanting had a greater positive impact in reducing water stress than the stomatal blockage due to the film-forming antitranspirant spray. Reapplying the antitranspirant 2 weeks after the initial spray at transplanting may have contributed to more dry matter accumulation by reducing transpiration from both the newer and older leaves. The use of antitranspirants has been shown to have short term effects and very few materials significantly reduce transpiration $>10 \mathrm{~d}$ (Kreith et al., 1975). Even short-term protection from water stress is highly desirable in transplanted crops.

Subtreatments also significantly affected plant growth in $1994(p \leq 0.01)$ (Table 5). Muskmelon plants experienced $10 \mathrm{~h}$ of high winds above $4 \mathrm{~m} \cdot \mathrm{s}^{-1}$ in the exposed areas within $24 \mathrm{~h}$ of transplanting. Plants treated with the polyacrylamide gel exhibited less wilting during this period than plants treated with the foliar antitranspirant spray or untreated plants. Again, the highest total fresh weight 21 DAT was achieved by the gel dip, followed by the control. The antitranspirant spray reduced early plant growth in sheltered areas by $19 \%$ compared to the control and $37 \%$ in exposed areas. This general pattern in fresh weight continued through the first 34 DAT. Dry weight changes followed the pattern of fresh weight with the gel dip treatment significantly increasing plant dry weight compared either the control or the antitranspirant spray by contrast analysis ( $p=0.0130$ dip vs control; $p$ $=0.0606$ spray vs control). These differences became less, although still significant through the 34 DAT. Growth of plants treated with the antitranspirant spray was reduced more relative to the control in exposed plots than in those that were wind protected.

Application of a gel dip in 1994 increased muskmelon LAI by $23 \%$ compared to untreated plants and the antitranspirant spray reduced muskmelon LAI by $37 \%$ in the first
21 DAT (Table 5). Plants treated with the spray were able to recover through compensatory growth between 21 and 34 DAT, there being no statistical differences detected by contrast analysis between the control and either the dip or spray subtreatments by 34 DAT.

Although there was not always a statistical difference, the plants treated with polyacrylamide gel were noticeably larger (greater LAI) than either control plants or plants treated with antitranspirant spray. Nitzsche et al. (1991) working with transplanted bell pepper treated with Folicote as a foliar dip found similar growth reduction relative to the untreated plants the second and third weeks after transplanting to the field when water stress occurred. They attributed this growth reduction to phytotoxicity of the antitranspirant formulation. The following year, when transplants were stressed by delaying irrigation for 6 DAT, pepper transplants treated with the antitranspirant had higher leaf water potential and growth was enhanced over the untreated plants (Nitzsche et al., 1991). The antitranspirant may provide an advantage in altering root/shoot ratios toward root development following transplanting. Unfortunately, we did not obtain root growth measurements.

Using a polyacrylamide gel in the root zone at transplanting had a greater tendency to increase dry weight and leaf area indices in the plants than the application of antitranspirant sprayed on the leaves. Plants treated with antitranspirant, however, had compensatory growth by 5 weeks after application. Although weather conditions during the 3 years of this study were typical of Nebraska only in the variability, we conclude that the use of polyacrylamide gel shows more potential to reduce transplant stress from desiccating winds than the use of antitranspirant sprays. However, neither treatment had as consistently significant an effect or as large an effect on early muskmelon growth as wind protection provided by tree windbreaks. Windbreaks created conditions that included slight but significantly warmer soil temperatures and significantly lower wind velocities that resulted in large increases in muskmelon plant growth that persisted through the growing season. 


\section{Literature Cited}

Baldwin, C.S. 1988. The influence of field windbreaks on vegetable and specialty crops, $p$. 191-203. In: J.R. Brandle, D.L. Hintz, and J.W. Sturrock (eds.). Windbreak technology. Agriculture, ecosystem, and environment. vol. 22-23.Elsivier Science Publ., Amsterdam.

Brandle, J.R., L. Hodges, and X.H. Zhou. 2004. Windbreaks in North American agricultural systems, p. 65-78. In: P.K.R. Nair, M.R. Rao, and L.E. Buck (eds.). New vistas in agroforestry: A compendium for the 1st world congress of agroforestry. vol. 1. Advances in agroforestry. Kluwer Academic Publ., Dordrecht, Netherlands.

Christiansen, M.N. and E.N. Ashworth. 1978. Prevention of chilling injury to seedling cotton with anti-transpirants. Crop Sci. 18:907-908.

El-Sayed, S.F. 1991. Growth and yield of snap bean under cold conditions as affected by growth regulators and pinolene. Scientia Hort. 47:3-4.
Gehring, J.M. and J.W. Lewis. 1980. Effect of hydrogel on wilting and moisture stress of bedding plants. J. Amer. Soc. Hort. Sci. 105:511-513.

Han, J.S. 1990. Use of antitranspirant epidermal coatings for plant protection in China. Plant Disease 74:263-266.

Hodges, L., M.N. Suratman, J.R. Brandle, and K.G. Hubbard. 2004. Growth and yield of snap beans (Phaseolus vulgaris L.) as affected by wind protection and microclimate changes due to shelterbelts and planting date. HortScience 39:996-1004.

Hunt, Roderick. 1982. Plant growth curves : the functional approach to plant growth analysis. University Park Press, Baltimore, Maryland.

Kreith, F.A., A. Taori, and J.E. Anderson. 1975. Persistence of selected antitranspirants. Water Resour. Res. 11:281-286.

Nitzsche, P., G.A. Berkowitz, and J. Rabin. 1991. Development of a seedling-applied antitranspirant formulation to enhance water status, growth and yield of transplanted bell pepper. J. Amer. Soc. Hort. Sci. 116:405-411.

Sasson, N. and W.J. Bramlage. 1981. Effects of chemical protectants against chilling injury of young cucumber seedlings. J. Amer. Soc. Hort. Sci. 106:282-284.

Semeniuk, P., H.E. Moline, and J.A. Abbott. 1986. A comparison of the effects of $\mathrm{ABA}$ and an antitranspirant on chilling injury of coleus, cucumbers, and diffenbachia. J. Amer. Soc. Hort. Sci. 111:866-868.

Van Eimern, J., R. Karschon, L.A. Razuinova, and G.W. Robertson. 1964. Windbreaks and shelterbelts. W.M.O. Tech. Note No. 59. WMO No. 147 , TP. 70.

Zhang, D., J.R. Brandle, L. Hodges, E. Daningsih, and K.G. Hubbard. 1999. The response of muskmelon growth and development to microclimate modification by shelterbelts HortScience 34:64-68. 